Jurnal Ilmu Ilmu Agribisnis: Journal of Agribusiness Science, 9(4), November 2021

\title{
EFISIENSI TEKNIS, STRUKTUR BIAYA, DAN PENDAPATAN PENANGKARAN BENIH PADI INBRIDA DI KECAMATAN BUMI RATU NUBAN KABUPATEN LAMPUNG TENGAH
}

\author{
(Technical Efficiency, Cost Structure, and Income of Inbrida Rice Seed Breeding in Bumi Ratu Nuban \\ Subdistrict of Central Lampung Regency)
}

Arif Adha Kenamon, Fembriarti Erry Prasmatiwi, Lina Marlina

Jurusan Agribisnis, Fakultas Pertanian, Universitas Lampung. Jl. Prof. Dr. Sumantri Brojonegoro No. 1 Bandar Lampung, 35145, E-mail: fembriarti.erry@fp.unila.ac.id

\begin{abstract}
The purposes of this research are analyze technical efficiency, factors that affecting technical efficiency, cost structure, break even point, and income of inbred rice seed breeding. Furthermore, this research uses a survey method. The location of the research is chosen purposively in Bumi Ratu Nuban Subdistrict Central Lampung Regency as consideration that there are active and sustainable groups of farmer on inbred rice seed breeding. It should be noted that the number of respondent is 44 farmers which are collected randomly. Additionally, this research was conducted since August-September 2019. The analytical method uses frontier production function, multiple linear regression model, independent sample t-test, cost structure, break even point, and income analysis. The result shows that the level of technical efficiency is quiet efficient by 78.13 percent. Factors that significantly affecting technical efficiency are farming cost, revenue, capital, and land ownership status. The biggest cost component of cost structure for total cost is labor cost by 46.29 percent. Finally, the inbred rice seed breeding is profitable, because BEP value is smaller than revenue, production, and price that obtained by farmers and $R / C$ for total cost is more than 1.
\end{abstract}

Key words: cost structure, inbred rice seed breeding, income, technical efficiency

\section{PENDAHULUAN}

Subsektor tanaman pangan merupakan salah satu subsektor pertanian yang strategis untuk pembangunan nasional. Keberhasilan pembangunan nasional tersebut akan berpengaruh terhadap ketahanan dan pertahanan nasional serta perekonomian nasional. Subsektor tanaman pangan sebagai sumber kebutuhan paling pokok bagi kehidupan nasional dan menopang kehidupan lebih dari 60\% pelaku usaha pertanian di Indonesia (Direktorat Jenderal Tanaman Pangan 2018). Salah satu komoditas tanaman pangan yang mempunyai peran penting dalam ketahanan dan pertahanan nasional adalah tanaman padi.

Provinsi Lampung merupakan salah satu sentra produksi padi di Indonesia. Menurut Dinas Pertanian Tanaman Pangan dan Hortikultura (TPH) Provinsi Lampung (2017), rata-rata produksi padi di Provinsi Lampung pada tahun 2013-2017 mengalami fluktuasi dengan rata-rata produktivitas sebesar 5,07 ton/ha. Peningkatan produktivitas padi di Provinsi Lampung dapat dilakukan dengan cara intensifikasi pertanian.
Salah satunya yaitu melalui penggunaan benih bermutu varietas unggul baru yang bersertifikat. Kebutuhan benih padi bersertifikat di Provinsi Lampung tahun 2017 sebesar 20.933,75 ton, sedangkan produksi benih padi bersertifikat tahun 2017 sebesar 10.668,22 ton, sehingga terdapat kekurangan benih padi bersertifikat sebesar $10.375,53$ ton. Oleh karena itu, keberadaan petani penangkar di Provinsi Lampung sangat penting untuk memenuhi kebutuhan benih bersertifikat secara berkelanjutan.

Menurut BPSBTPH Provinsi Lampung (2018), salah satu kabupaten yang menjadi sentra produksi benih padi bersertifikat yaitu Kabupaten Lampung Tengah dengan luas lahan sebesar 1.573 hektar. Produksi benih padi bersertifikat di Provinsi Lampung sebesar $10.688,22$ ton dan luas panen 5.741,30 hektar. Produktivitas benih padi bersertifikat sebesar 1,86 ton/ha. Hasil tersebut masih jauh di bawah produktivitas potensial Kementerian Pertanian yaitu sebesar 6 ton/ha. Selain itu, harga jual calon benih padi berkisar Rp3.500,00/kg - Rp4.000,00/kg. Hal ini menjadi indikator bahwa produktivitas benih padi inbrida 
belum efisien secara teknis dan menyebabkan pendapatan yang diterima petani menjadi rendah.

Tingkat produktivitas benih padi yang rendah disebabkan oleh perubahan iklim yang tidak menentu dan varietas tanaman rentan terhadap hama wereng. Tingkat penerapan teknologi baru oleh petani dan pengetahuan yang dimiliki petani masih tergolong rendah yang akan berdampak pada peluang menurunnya hasil produksi benih padi bersertifikat. Penggunaan faktor-faktor produksi penangkaran benih padi inbrida yang belum optimal diduga dapat membuat produktivitas menjadi rendah. Menurut Misgiantoro, Prasmatiwi, dan Nurmayasari (2017) bahwa keberhasilan suatu usahatani dipengaruhi oleh faktor internal dan eksternal. Faktor internal antara lain penggunaan pupuk, benih, lahan, pestisida, dan tenaga kerja, sedangkan faktor eksternal antara lain fasilitas kredit, lembaga penunjang pertanian, dan harga yang sedang berlaku. Pengoptimalan penggunaan faktor-faktor produksi tersebut diharapkan dapat meningkatkan produksi dan produktivitas serta berpengaruh terhadap pendapatan petani.

Petani penangkaran benih padi inbrida di Kecamatan Bumi Ratu Nuban tidak melakukan pencatatan terhadap biaya-biaya dan curahan tenaga kerja yang dikeluarkan, sehingga perlu adanya penelitian tentang besarnya biaya dan persentase struktur biaya produksi. Analisis tersebut dapat mengetahui biaya yang berkontribusi sangat besar terhadap penangkaran benih padi inbrida. Selain itu, terdapat juga analisis tentang titik impas, sehingga dapat diketahui penangkaran yang dilakukan menguntungkan atau tidak bagi petani. Tujuan dari penelitian ini adalah menganalisis tingkat efisiensi teknis penggunaan faktor produksi, menganalisis faktor-faktor yang mempengaruhi efisiensi teknis, menganalisis struktur biaya, menganalisis break even point, dan pendapatan penangkaran benih padi inbrida.

\section{METODE PENELITIAN}

Metode penelitian ini menggunakan metode survei. Penelitian ini dilakukan di Kampung Bumi Ratu dan Tulung Kakan, Kecamatan Bumi Ratu Nuban, Kabupaten Lampung Tengah. Pemilihan lokasi penelitian dilakukan secara sengaja (purposive) dengan pertimbangan bahwa di lokasi tersebut terdapat kelompok tani yang aktif dan berkelanjutan dalam melakukan penangkaran benih padi inbrida. Selain itu, berdasarkan informasi dari
BPSBTPH Provinsi Lampungbahwa produksi benih padi inbrida sudah bersertifikat dan memiliki label.

Metode pengambilan sampel dilakukan secara Simple Random Sampling. Populasi penangkaran di lokasi penelitian sebanyak 105 responden yang tersebar di tiga kelompok tani. Berdasarkan populasi tersebut ditentukan jumlah sampel menggunakan rumus yang merujuk pada teori Sugiarto et al (2003), sehingga didapatkan sampel berjumlah 44 responden yang tersebar di tiga kelompok tani yaitu 13 responden kelompok tani Sido Bangun 1, 16 responden kelompok tani Sido Bangun 3, dan 15 responden kelompok tani Amanah. Data yang digunakan dalam penelitian ini adalah data primer dan data sekunder. Pengambilan data dilaksanakan pada bulan Agustus-September 2019. Analisis data yang digunakan dalam penelitian ini adalah analisis deskriptif kuantitatif. Analisis efisiensi teknis dilakukan dengan cara membandingkan antara produksi aktual dengan produksi potensial atau produksi frontier sebagai berikut (Soekartawi 2003):

$$
\begin{aligned}
\log Y_{i}= & b_{0}+b_{1} \log X_{1}+b_{2} \log X_{2}+b_{3} \log X_{3}+b_{4} \\
& \log X_{4}+b_{5} \log X_{5}+b_{6} \log X_{6}+b_{7} \log X_{7}+ \\
& b_{8} \log X_{8}+b_{9} \log X_{9}+b_{10} \log X_{10} \ldots \ldots \ldots(1)
\end{aligned}
$$

Keterangan:

Yi $=$ Hasil produksi aktual penangkaran benih padi inbrida ke-i $(\mathrm{i}=1, \ldots \mathrm{n})$

$\mathrm{Xi}=$ Faktor produksi yang digunakan

$\mathrm{X} 1$ =Luas lahan (ha)

$\mathrm{X} 2=$ Jumlah benih $(\mathrm{kg})$

X3 = Jumlah pupuk Urea $(\mathrm{kg})$

X4 =Jumlah pupuk NPK Phonska $(\mathrm{kg})$

X5 =Jumlah pupuk SP-36 $(\mathrm{kg})$

$\mathrm{X} 6=$ Jumlah pupuk $\mathrm{KCl}(\mathrm{kg})$

X7 =Jumlah herbisida (gba)

$\mathrm{X} 8$ =Jumlah fungisida (gba)

$\mathrm{X} 9=$ Jumlah insektisida (gba)

$\mathrm{X} 10=$ Jumlah tenaga kerja (HOK)

$\mathrm{a} 0, \mathrm{a} 1=$ Parameter yang diduga

Pendugaan fungsi produksi frontier menggunakan linear programming yang diolah dengan software lindo sebagai berikut (Soekartawi 2003):

$$
\begin{aligned}
& \text { Minimalkan } \quad \mathrm{b}_{0}+\sum_{\mathrm{j}=1}^{10} \mathrm{~b}_{\mathrm{j}} \mathrm{X}_{\mathrm{j}} \\
& \text { Dengan syarat } b_{0}+\sum_{j=1}^{10} b_{j} X_{1 j} \geq Y_{1} \\
& b_{0}+\sum_{j=1}^{10} b_{j} X_{2 j} \geq Y_{2} \\
& \mathrm{~b}_{0}+\sum_{\mathrm{j}=1}^{10} \mathrm{~b}_{\mathrm{j}} \mathrm{X}_{\mathrm{nj}} \geq \mathrm{Y}_{\mathrm{n}}
\end{aligned}
$$


Fungsi frontier diperoleh dengan cara memasukkan penggunaan faktor produksi ke dalam fungsi frontiersebagai berikut (Soekartawi 2003):

$\mathrm{Y}_{\mathrm{f}}=\mathrm{b}_{0}+\sum_{\mathrm{j}=1}^{10} \mathrm{~b}_{\mathrm{j}} \mathrm{X}_{\mathrm{ij}}+\mathrm{e}_{\mathrm{i}}$

Efisiensi teknis masing-masing dapat dihitung dengan rumus sebagai berikut (Soekartawi 2003):

$\mathrm{ET}=\frac{\mathrm{Y}_{\mathrm{i}}}{\mathrm{Y}_{\mathrm{f}}} \times 100 \%$

\section{Keterangan:}

ET = Tingkat efisiensi teknis

$\mathrm{Yi}=$ Produksi aktual ke-i

Yf $=$ Produksi potensial/frontier ke-i

Persamaan yang digunakan untuk analisis regresi linear berganda dituliskan kedalam persamaan berikut (Soekartawi 2003):

$$
\begin{aligned}
\ln \mathrm{Y}= & \mathrm{b}_{0}+\mathrm{b}_{1} \ln \mathrm{Z1}+\mathrm{b}_{2} \ln \mathrm{Z2}+\mathrm{b}_{3} \ln \mathrm{Z3}+\mathrm{b}_{4} \ln \mathrm{Z4} \\
& +\mathrm{b}_{5} \ln \mathrm{Z5}+\mathrm{b}_{7} \mathrm{D}_{1}+\mathrm{b}_{8} \mathrm{D}_{2}+\mathrm{e} \ldots \ldots \ldots \ldots \ldots \ldots .(8)
\end{aligned}
$$

Keterangan:

LnY =Efisiensi teknis

LnZ1 =Umur (tahun)

LnZ2 $=$ Pendidikan (tahun)

LnZ3 = Pengalaman penangkaran (tahun)

LnZ4 = Biaya usahatani (Rp)

LnZ5 =Penerimaan $(\mathrm{Rp})$

D1 =Sumber modal $(1=$ pinjaman dan modal sendiri dan $0=$ modal sendiri)

D2 =Status kepemilikan lahan $(1=$ milik sendiri dan $0=$ non milik)

Kesesuaian model dengan kriteria statistik dilihat dari nilai koefisien determinasi $\left(\mathrm{R}^{2}\right)$, hasil uji simultan (F-hitung), dan uji parsial (t-hitung). Selain itu, dilakukan uji asumsi klasik yang terdiri dari uji normalitas, uji multikolinearitas, dan uji heteroskedastisitas, agar kondisi model tersebut BLUE (Best Linear Unbiased Estimate) atau valid untuk memprediksi.

Uji normalitas dengan cara uji Kolmogorov Smirnov dengan melihat nilai Asymp. Sig.> 0,05, maka data residual berdistribusi normal. Uji multikolinearitas dengan melihat nilai VIF $<10$, maka tidak terdapat gejala multikolinearitas antar variabel independen. Uji heteroskedastisitas dapat diketahui dengan cara uji White dengan melihat nilai Prob. Chi-Square > 0,05, maka tidak ada heteroskedastisitas.
Persentase dari setiap struktur biaya produksi menurut Suripatty (2011) dapat dihitung menggunakan rumus sebagai berikut:

$\mathrm{P}=\frac{\mathrm{NTFC} \text { atau NTVC }}{\mathrm{NTC}} \times 100 \%$

Keterangan:

$\mathrm{P} \quad=$ Nilai dari struktur biaya produksi

NTFC =Nilai dari tiap komponen biaya tetap

NTVC $=$ Nilai dari tiap komponen biaya variabel

NTC $=$ Nilai dari total biaya produksi

Analisis titik impas (break event point) menurut Suratiyah (2015) rumus BEP sebagai berikut:

BEP Penerimaan $(\mathrm{Rp})=\frac{\mathrm{FC}}{1-\frac{\mathrm{VC}}{\mathrm{R}}}$

BEP Produksi $(\mathrm{kg})=\frac{\mathrm{FC}}{\mathrm{P}-\mathrm{AVC}}$

BEP Harga $(\mathrm{Rp} / \mathrm{kg})=\frac{\mathrm{TC}}{\mathrm{Y}}$

Keterangan:

BEP Penerimaan $=$ Titik impas penerimaan $(\mathrm{Rp})$

BEP Produksi $=$ Titik impas produksi $(\mathrm{kg})$

BEP Harga =Titik impas harga $(\mathrm{Rp} / \mathrm{kg})$

FC $\quad=$ Biaya tetap $(\mathrm{Rp})$

$\mathrm{VC}=$ Biaya variabel $(\mathrm{Rp})$

$\mathrm{TC} \quad=$ Total biaya $(\mathrm{Rp})$

AVC $\quad=$ Biaya variabel per unit $(\mathrm{Rp} / \mathrm{kg})$

$\mathrm{Y} \quad=$ Produksi total $(\mathrm{kg})$

$\mathrm{P} \quad=$ Harga $(\mathrm{Rp} / \mathrm{kg})$

$\mathrm{R} \quad \quad=$ Penerimaan $(\mathrm{Rp})$

Perhitungan pendapatan menurut Soekartawi (1995) sebagai berikut:

$\pi=\mathrm{TR}-\mathrm{TC}=\left(\mathrm{Y} \cdot \mathrm{P}_{\mathrm{y}}\right)-\left(\sum \mathrm{X}_{\mathrm{i}} \cdot \mathrm{Px}_{\mathrm{i}}+\mathrm{BTT}\right) \ldots$

Keterangan:

$\pi \quad=$ Pendapatan usahatani

$\mathrm{TR}=$ Penerimaan total

$\mathrm{TC}=$ Biaya total

$\mathrm{Y}=$ Hasil produksi $(\mathrm{kg})$

Py =Harga hasil produksi (Rp)

$\mathrm{Xi}=$ Faktor produksi variabel ke-i $(1,2,3,4, \mathrm{n})$

Pxi $=$ Harga faktor produksi variabel ke-i (Rp/satuan)

BTT $=$ Biaya tetap total

Menurut Rahim dan Hastuti (2008), analisis Return Cost Ratio (R/C) adalah perbandingan antara penerimaan dan biaya. Rumus sebagai berikut:

$\mathrm{R} / \mathrm{C}=\frac{\mathrm{TR}}{\mathrm{TC}}$

Keterangan: 
$\mathrm{R} / \mathrm{C}=$ Nisbah antara penerimaan dengan biaya

$\mathrm{TR}=$ Penerimaan total

$\mathrm{TC}=$ Biaya total

Dengan kriteria pengambilan keputusan sebagai berikut:

a. Jika R/C $>1$, maka usahatani mengalami keuntungan

b. Jika $\mathrm{R} / \mathrm{C}<1$, maka usahatani mengalami kerugian

c. Jika $\mathrm{R} / \mathrm{C}=1$, maka usahatani berada pada titik impas (tidak untung atau tidak rugi)

\section{HASIL DAN PEMBAHASAN}

\section{Keragaan Penangkaran Benih Padi Inbrida}

Luas lahan penangkaran berkisar antara 0,16-1 hektar dengan rata-rata sebesar 0,58 hektar. Mayoritas luas lahan penangkaran yaitu $\geq 0,50$ hektar sebanyak 70,45 persen. Petani yang memiliki lahan sendiri sebanyak 68,18 persen dengan rata-rata luas lahan sebesar 0,64 hektar dan petani yang memiliki lahan sakap sebanyak 31,82 persen dengan rata-rata luas lahan sebesar 0,46 hektar.

Penangkaran di Kecamatan Bumi Ratu Nubanditanam awal bulan Januari dan dipanen pertengahan bulan April 2019. Kegiatan penangkaran pada musim tersebut terdapat program kerjasama dengan produsen benih. Petani yang mengikuti program kerjasama mendapatkan bantuan berupa benih pokok (BP) varietas Situ Bagendit dan hasil panennya akan dibeli kembali oleh produsen benih. Sebesar 70,45 persen menyatakan bahwa petani melakukan penangkaran, karena harga jual yang lebih tinggi.

Budidaya penangkaran benih padi inbrida memerlukan perhatian dan penanganan yang tepat dan benar guna mendapatkan calon benih yang bermutu. Kegiatan penangkaran harus dilakukan lebih intensif dari padi konsumsi, karena kegiatan yang dilakukan berbeda yaitu terdapat kegiatan roguing atau seleksi yang dilakukan oleh produsen benih. Roguing bertujuan untuk membuang atau menyeleksi rumpun-rumpun tanaman calon benih padi yang ciri-ciri morfologisnya menyimpang. Roguing dilakukan tiga kali yaitu pertama pada saat calon benih padi mulai berisi, kedua pada saat calon benih padi mulai menguning, dan ketiga pada saat calon benih padi akan dipanen. Pengairan berasal dari sistem irigasi yang dibayarkan setiap musimnya.
Sumber modal petani mayoritas berasal dari modal pinjaman sebanyak 56,82 persen yang berasal dari kelompok tani berupa sarana produksi dan kesepakatan pengembalian pinjaman setelah panen. Petani yang menggunakan modal sendiri sebanyak 43,18 persen.

\section{Penggunaan Sarana Produksi}

Benih yang digunakan petani yaitu benih pokok dengan varietas Situ Bagendit. Penggunaan benih rata-rata sebesar $24,36 \mathrm{~kg} / \mathrm{ha}$. Penggunaan benih hampir mendekati anjuran yaitu 25,00 kg/ha. Penggunaan pupuk Urea, NPK Phonska, SP-36, dan $\mathrm{KCl}$ secara berturut-turut yaitu $281,79 \mathrm{~kg} / \mathrm{ha}$, $231,08 \mathrm{~kg} / \mathrm{ha}, 203,59 \mathrm{~kg} / \mathrm{ha}$, dan 43,10 kg/ha. Penggunaan pupuk sudah melebihi anjuran, kecuali pupuk $\mathrm{KCl}$ belum sesuai anjuran.

Penggunaan obat-obatan oleh petani sebanyak 88,64 persen menggunakan obat Plenum 50 WG, karena menurut petani obat tersebut ampuh untuk mengendalikan hama wereng. Selain itu, petani juga banyak menggunakan obat Manuver $400 \mathrm{SL}$, Gramoxone 276 SL, Ally Plus 77 WP, dan Score 250 EC. Hama wereng merupakan hama yang intensitas serangannya paling tinggi, sehingga menyebabkan tamanan banyak yang rusak. Selain itu, terdapat hama ulat, walang sangit, tikus, sundep, belalang, dan lembing, sedangkan penyakit yang menyerang yaitu patah leher dan jamur.

Penggunaan tenaga kerja sebanyak 83,22 HOK/ha. Penggunaan peralatan oleh petani yang dimiliki sendiri yaitu cangkul, sprayer, golok, dan arit, sedangkan alat hand tractor dan combine harvester menyewa.

\section{Produksi dan Penerimaan Penangkaran Benih Padi Inbrida}

Rata-rata produksi sebesar 4.192,67 kg/ha. hasil tersebut menunjukkan bahwa produksi masih rendah dibandingkan dengan target pemerintah yaitu 6 ton/ha. Rata-rata harga jual calon benih padi sebesar $\mathrm{Rp} 4.125,00 / \mathrm{kg}$, sehingga rata-rata penerimaan yang diperoleh petani sebesar Rp17.509.945,40/ha.

\section{Efisiensi Teknis Penangkaran Benih Padi Inbrida}

Tabel 1 menunjukkan bahwa variabel-variabel yang berpengaruh terhadap produksi penangkaran benih padi inbrida yaitu benih, pupuk SP-36, 
Tabel 1. Hasil pendugaan koefisien regresi fungsi produksi frontier penangkaran benih padi inbrida

\begin{tabular}{lc}
\hline \multicolumn{1}{c}{ Variabel } & Koefisien \\
\hline Konstanta & 2,174957 \\
Log X1 (Luas Lahan) & 0,000000 \\
Log X2 (Benih) & 0,254193 \\
Log X3 (Pupuk Urea) & 0,000000 \\
Log X4 (Pupuk NPK Phonska) & 0,000000 \\
Log X5 (Pupuk SP-36) & 0,047395 \\
Log X6 (Pupuk KCl) & 0,009092 \\
Log X7 (Herbisida) & 0,002355 \\
Log X8 (Fungisida) & 0,010712 \\
Log X9 (Insektisida) & 0,032255 \\
Log X10 (Tenaga Kerja) & 0,534452 \\
\hline
\end{tabular}

pupuk $\mathrm{KCl}$, herbisida, fungisida, insektisida, dan tenaga kerja, apabila variabel-variabel tersebut ditambahkan satu persen, maka akan meningkatkan produksi sebesar nilai koefisien regresinya masingmasing.

Variabel luas lahan, pupuk urea, dan pupuk NPK Phonska memiliki nilai koefisien sama dengan nol, apabila penggunaan input tersebut ditambah maka tidak akan meningkatkan produksi. Hasil yang diperoleh berdasarkan pengolahan data yaitu ratarata produksi frontier (Yf) sebesar 5.324,38 kg/ha dan rata-rata produksi aktual ( $\mathrm{Y}$ aktual) sebesar 4.192,67 kg/ha. Rata-rata tingkat efisiensi tergolong cukup efisien yaitu 78,13 persen. Secara individu, sebaran tingkat efisiensi teknis berkisar $36,47-100,00$ persen.

Tabel 2 menunjukkan bahwa mayoritas petani berada di klasifikasi 70,00 - 89,99 persen sebesar 36,36 persen. Tingkat efisiensi teknis pada penelitian ini lebih rendah dibandingkan penelitian Ulpah, Tinaprilla, dan Baga (2018) sebesar 92,00 persen dan penelitian Tristya, Murniati, dan Affandi (2018) sebesar 93,00 persen. Tingkat efisiensi teknis pada penelitian ini lebih tinggi dibandingkan penelitian Noer, Zakaria, dan Murniati (2018) sebesar 71,00 persen dan penelitian Indah, Zakaria, dan Prasmatiwi (2015).

\section{Faktor-Faktor yang Mempengaruhi Efisiensi Teknis Penangkaran Benih Padi Inbrida}

Hasil analisis regresi faktor-faktor yang mempengaruhi efisiensi teknis pada Tabel 3 menunjukkan bahwa data berdistribusi normal, karena hasil uji normalitas menggunakan uji KolmogorovSmirnov mempunyai nilai Asymp. Sig. $=0,200>0,05$. Hasil uji multikolinearitas
Tabel 2. Sebaran petani penangkaran benih padi inbrida berdasarkan tingkat efisiensi teknis

\begin{tabular}{cccc}
\hline $\begin{array}{c}\text { Klasifikasi } \\
(\%)\end{array}$ & $\begin{array}{c}\text { Persentase } \\
(\%)\end{array}$ & Keterangan & $\begin{array}{c}\text { Rata-Rata } \\
\text { Efisiensi } \\
\text { Teknis (\%) }\end{array}$ \\
\hline$<70,00$ & 29,55 & Belum Efisien & \\
$70,00-89,99$ & 36,36 & Cukup Efisien & 78,13 \\
$90,00-$ & 34,09 & Sudah Efisien & \\
100,00 & & & \\
\hline Jumlah & 100,00 & & \\
\hline
\end{tabular}

menunjukkan bahwa nilai VIF $<10$, sehingga data tidak terdapat multikolinearitas dan hasil uji heteroskedastisitas menggunakan uji White menunjukkan bahwa nilai Prob. Chi-Squared $=$ $0,062>0,05$, sehingga data tidak terdapat heteroskedastisitas.

Nilai $R$-Squared sebesar 65,80 persen variasi efisiensi teknis penangkaran benih padi inbrida dapat dijelaskan oleh variabel umur, pendidikan, pengalaman penangkaran, biaya, penerimaan, sumber modal, dan status kepemilikan lahan yang dimasukkan kedalam model, sedangkan sisanya sebesar 34,20 persen dapat dijelaskan oleh variabel lain yang tidak dimasukkan ke dalam model. Nilai F-hitung sebesar 9,896 dengan nilai Sig. sebesar 0,000 yang berarti bahwa secara bersama-sama variabel umur, pendidikan, pengalaman penangkaran, biaya, penerimaan, sumber modal, dan status kepemilikan lahan berpengaruh nyata terhadap efisiensi teknis penangkaran benih padi inbrida dengan tingkat kepercayaan 99 persen.

Hasil uji-t menunjukkan bahwa variabel biaya, penerimaan, sumber modal, dan status kepemilikan lahan berpengaruh nyata terhadap efisiensi teknis penangkaran benih padi inbrida. Nilai koefisien regresi biaya bertanda negatif $(-0,541)$ yang artinya bahwa apabila biaya ditambahkan satu persen, maka akan mengurangkan efisiensi teknis sebesar 0,541 persen. Hasil penelitian ini sejalan dengan penelitian Misgiantoro et al. (2017) bahwa semakin besar biaya yang dikeluarkan maka efisiensi teknis akan menurun. Nilai koefisien regresi penerimaan bertanda positif $(0,651)$ yang artinya bahwa apabila penerimaan bertambah satu persen, maka akan meningkatkan efisiensi teknis sebesar 0,651 persen. Hasil penelitian ini sejalan dengan penelitian Ambarita, Prasmatiwi, dan Nugraha (2014) bahwa apabila petani mampu mengalokasikan faktor produksi dengan baik, maka hasil usahatani meningkat. 
Tabel 3. Hasil analisis regresi faktor-faktor yang mempengaruhi efisiensi teknis penangkaran benih padi inbrida

\begin{tabular}{|c|c|c|c|c|}
\hline Variabel & Koefisien & t-hitung & Sig. & VIF \\
\hline Konstanta & $2,125 * *$ & 2,220 & 0,033 & \\
\hline LnZ1 (Umur) & 0,041 & 0,315 & 0,755 & 1,197 \\
\hline LnZ2 (Pendidikan) & 0,006 & 0,455 & 0,652 & 1,149 \\
\hline $\begin{array}{l}\text { LnZ3 (Pengalaman } \\
\text { Penangkaran) }\end{array}$ & 0,052 & 0,948 & 0,350 & 1,139 \\
\hline LnZ4 (Biaya Usahatani) & $-0,541 * * *$ & $-5,071$ & 0,000 & 4,031 \\
\hline LnZ5 (Penerimaan) & $0,651 * * *$ & 7,263 & 0,000 & 3,970 \\
\hline D1 (Sumber Modal) & $0,113^{*}$ & 1,808 & 0,079 & 1,316 \\
\hline $\begin{array}{l}\text { D2 (Status Kepemilikan } \\
\text { Lahan) }\end{array}$ & $-0,328 * * *$ & $-3,969$ & 0,000 & 2,037 \\
\hline$R$-Squared & & 0,658 & & \\
\hline Adjusted R-Squared & & 0,592 & & \\
\hline F-hitung & & 9,896 & & \\
\hline Sig. (F-hitung) & & 0,000 & & \\
\hline 1-Sample K-S Test Statist & & 0,076 & & \\
\hline Asymp. Sig. (2-tailed) & & 0,200 & & \\
\hline $\begin{array}{l}\text { Keterangan: } \\
* * *=\text { Nyata pada taraf kepe } \\
* * \quad=\text { Nyata pada taraf kepe } \\
* \quad=\text { Nyata pada taraf kepe }\end{array}$ & $\begin{array}{l}\text { ercayaan } 991 \\
\text { ercayaan } 95 \\
\text { ercayaan } 90\end{array}$ & $\begin{array}{l}\text { rsen } \\
\text { rsen } \\
\text { rsen }\end{array}$ & & \\
\hline
\end{tabular}

Nilai koefisien regresi status kepemilikan lahan bertanda negatif $(0,328)$ yang artinya bahwa apabila petani menggunakan lahan milik sendiri, maka tingkat efisiensi teknis akan berkurang sebesar 0,328 persen. Sebaran efisiensi teknis petani yang memiliki lahan sendiri $(77,59 \%)$ lebih rendah dari pada petani yang menggunakan lahan sakap $(79,29 \%)$.

Nilai koefisien regresi sumber modal bertanda positif $(0,113)$ yang artinya bahwa apabila sumber modal petani berasal dari pinjaman dan modal sendiri, maka efisiensi teknis akan meningkat sebesar 0,113 persen. Kondisi ini karena petani yang sumber modalnya dari pinjaman menggunakan modalnya dengan baik dan melakukan kegiatan penangkaran lebih giat, sehingga petani dapat mengembalikan modal yang sudah dipinjamnya.

\section{Struktur Biaya Penangkaran Benih Padi Inbrida}

Tabel 4 menunjukkan bahwa kontribusi biaya variabel terhadap biaya total sebesar 68,76 persen lebih tinggi dibandingkan kontribusi biaya tetap terhadap biaya total sebesar 31,24 persen. Biaya tenaga kerja merupakan biaya yang berkontribusi sangat besar terhadap biaya total sebesar 46,29 persen karena petani menggunakan tenaga kerja pengolahan lahan, penanaman, dan pemanenan secara borongan. Biaya sewa lahan menjadi kontribusi terbesar kedua sebesar 17,79 persen, karena rata-rata biaya sewa lahan sawah sebesar
Tabel 4. Struktur biaya penangkaran benih padi inbrida per hektar

\begin{tabular}{|c|c|c|c|c|}
\hline Komponen Biaya & $\begin{array}{l}\text { Rata-Rata } \\
\text { Biaya (Rp) }\end{array}$ & $\begin{array}{c}\text { Biaya } \\
\text { Tetap } \\
(\%)\end{array}$ & $\begin{array}{c}\text { Biaya } \\
\text { Variabel } \\
(\%)\end{array}$ & $\begin{array}{c}\text { Biaya } \\
\text { Total } \\
(\%)\end{array}$ \\
\hline \multicolumn{5}{|l|}{ Biaya Tetap } \\
\hline Pajak Lahan & $34.469,38$ & 0,88 & & 0,27 \\
\hline Sewa Lahan & $2.239 .469,58$ & 56,95 & & 17,79 \\
\hline Lahan Sakap & 1.307 .78 & 33,26 & & 10,39 \\
\hline Penyusutan Alat & & 2,98 & & 0,93 \\
\hline Irigasi & & 5,93 & & 1,85 \\
\hline Total Biaya Tetap & $3.932 .039,68$ & 100,00 & & 31,24 \\
\hline \multicolumn{5}{|l|}{ Biaya Variabel } \\
\hline Benih & $316.634,17$ & & 3,66 & 2,52 \\
\hline Pupuk Urea & $587.948,52$ & & 6,79 & 4,67 \\
\hline Pupuk NPK Phonska & $613.202,03$ & & 7,09 & 4,87 \\
\hline Pupuk SP-36 & $470.787,83$ & & 5,44 & 3,74 \\
\hline Pupuk KCl & $285.296,41$ & & 3,30 & 2,27 \\
\hline Obat-Obatan & $554.309,67$ & & 6,41 & 4,40 \\
\hline Tenaga Kerja & $5.825 .195,98$ & & 67,32 & 46,29 \\
\hline Total Biaya Variabel & 8.653.374,61 & & 100,00 & 68,76 \\
\hline Biaya Total & $12.585 .414,29$ & & & 100,00 \\
\hline
\end{tabular}

Rp2.239.469,58/ha/MT. lahan sakap menjadi kontribusi terbesar ketiga sebesar 10,39 persen. Biaya pupuk yang berkontribusi cukup besar yaitu pupuk NPK Phonska sebesar 4,87 persen dan pupuk Urea sebesar 4,67 persen. Biaya obatobatan yang dikeluarkan cukup besar yaitu sebesar 4,40 persen karena banyak hama dan penyakit yang menyerang tanaman terutama hama wereng.

Hasil penelitian ini tidak sejalan dengan penelitian Usman (2011) bahwa struktur biaya usahatani jagung terbesar yang dikeluarkan yaitu biaya sarana produksi sebesar 57,58 persen.

\section{Break Even Point Penangkaran Benih Padi Inbrida}

Hasil analisis BEP pada Tabel 5 menunjukkan bahwa nilai BEP penerimaan sebesar Rp7.773.866,63/ha, BEP produksi sebesar $1.907,77 \mathrm{~kg} / \mathrm{ha}$, dan BEP harga sebesar Rp3.001,77/kg. Hasil tersebut menunjukkan bahwa nilai BEP lebih kecil dibandingkan hasil yang diperoleh petani, sehingga penangkaran benih padi inbrida layak untuk dilaksanakan.

Tabel 5. BEP penangkaran benih padi inbrida per hektar

\begin{tabular}{lcr}
\hline \multicolumn{1}{c}{ Uraian } & Satuan & \multicolumn{1}{c}{ Nilai } \\
\hline BEP Penerimaan & $\mathrm{Rp}$ & $7.773 .866,63$ \\
BEP Produksi & $\mathrm{Kg}$ & $1.907,77$ \\
BEP Harga & $\mathrm{Rp} / \mathrm{kg}$ & $3.001,77$ \\
\hline
\end{tabular}


Hasil BEP penerimaan, produksi, dan harga pada penelitian ini lebih tinggi dibandingkan penelitian Geasti, Haryono, dan Affandi (2019) bahwa BEP penerimaan usahatani padi sebesar Rp5.291.805,05/ha, BEP produksi sebesar $1.846,84 \mathrm{~kg} / \mathrm{ha}$, dan BEP harga sebesar Rp1.012,76/kg.

\section{Pendapatan Penangkaran Benih Padi Inbrida}

Hasil analisis rata-rata penerimaan, biaya, pendapatan, dan R/C dapat dilihat pada Tabel 6 yang menunjukkan bahwa rata-rata penerimaan sebesar Rp17.509.945,40/ha, sedangkan biaya tunai dan biaya total yang dikeluarkan sebesar Rp8.311.114,92/ha dan Rp12.585.414,29/ha. Pendapatan atas biaya tunai dan biaya total yang diperoleh petani sebesar Rp9.198.830,47/ha dan Rp4.924.531,11/ha.

Tabel 6. Rata-rata penerimaan, biaya, pendapatan, dan $\mathrm{R} / \mathrm{C}$ penangkaran benih padi inbrida

\begin{tabular}{|c|c|c|c|c|}
\hline \multirow{2}{*}{ Uraian } & \multirow{2}{*}{ Satuan } & \multicolumn{3}{|c|}{1 hektar } \\
\hline & & Jumlah & Harga (Rp) & Nilai (Rp) \\
\hline \multicolumn{5}{|l|}{ Penerimaan } \\
\hline Produksi & $\mathrm{Kg}$ & $4.192,67$ & $4.125,00$ & $17.509 .945,40$ \\
\hline \multicolumn{5}{|l|}{ Biaya Produksi } \\
\hline \multicolumn{5}{|l|}{ Biaya Tunai } \\
\hline Pupuk Urea & $\mathrm{Kg}$ & 281,79 & $2.090,91$ & $587.948,52$ \\
\hline $\begin{array}{l}\text { Pupuk NPK } \\
\text { Phonska }\end{array}$ & $\mathrm{Kg}$ & 231,08 & $2.659,09$ & $613.202,03$ \\
\hline Pupuk SP-36 & $\mathrm{Kg}$ & 203,59 & $2.316,28$ & $470.787,83$ \\
\hline Pupuk KCl & $\mathrm{Kg}$ & 43,10 & $6.823,53$ & $285.296,41$ \\
\hline Obat-obatan & $\mathrm{Rp}$ & & & $554.309,67$ \\
\hline $\begin{array}{l}\text { TK Luar } \\
\text { Keluarga }\end{array}$ & $\mathrm{HOK}$ & 60,34 & $70.000,00$ & $4.223 .986,93$ \\
\hline Pajak Lahan & $\mathrm{Rp}$ & & & $34.469,38$ \\
\hline Lahan Sakap & $\mathrm{Rp}$ & & & $1.307 .787,31$ \\
\hline Irigasi & $\mathrm{Rp}$ & & & $233.326,83$ \\
\hline $\begin{array}{l}\text { Total Biaya } \\
\text { Tunai }\end{array}$ & $\mathrm{Rp}$ & & & $8.311 .114,92$ \\
\hline \multicolumn{5}{|c|}{ Biaya Diperhitungkan } \\
\hline Benih & $\mathrm{Kg}$ & 24,36 & $13.000,00$ & $316.634,17$ \\
\hline $\begin{array}{l}\text { TK Dalam } \\
\text { Keluarga }\end{array}$ & $\mathrm{HOK}$ & 22,87 & $70.000,00$ & $1.601 .209,05$ \\
\hline Sewa Lahan & $\mathrm{Rp}$ & & & $2.239 .469,58$ \\
\hline Penyusutan Alat & $\mathrm{Rp}$ & & & $116.986,57$ \\
\hline $\begin{array}{l}\text { Total Biaya } \\
\text { Diperhitungkan }\end{array}$ & $\mathrm{Rp}$ & & & $4.274 .299,36$ \\
\hline Total Biaya Produk & & & & $12.585 .414,29$ \\
\hline \multicolumn{5}{|l|}{ Pendapatan } \\
\hline $\begin{array}{l}\text { Pendapatan Atas } \\
\text { Biaya Tunai }\end{array}$ & $\mathrm{Rp}$ & & & $9.198 .830,47$ \\
\hline $\begin{array}{l}\text { Pendapatan Atas } \\
\text { Biaya Total }\end{array}$ & $\mathrm{Rp}$ & & & 4.924.531,11 \\
\hline \multicolumn{5}{|l|}{$\mathrm{R} / \mathrm{C}$} \\
\hline R/C Atas Biaya Tur & & & & 2,11 \\
\hline R/C Atas Biaya Tot & & & & 1,39 \\
\hline
\end{tabular}

Nilai R/C yang diperoleh lebih besar dari 1 yaitu $\mathrm{R} / \mathrm{C}$ atas biaya tunai sebesar 2,11 dan $\mathrm{R} / \mathrm{C}$ atas biaya total sebesar 1,39. Hasil penelitian ini sejalan dengan penelitian Mita, Haryono, dan Marlina (2018) bahwa nilai R/C lebih besar dari 1 dan layak untuk dilaksanakan. $\mathrm{R} / \mathrm{C}$ atas biaya total pada penelitian ini lebih besar dibandingkan penelitian Fermadi, Prasmatiwi, dan Kasymir (2015). R/C atas biaya total pada penelitian ini lebih rendah dibandingkan penelitian Handayani, Effendi, dan Viantimala (2017) sebesar 1,56 dan penelitian Saputra, Haryono, dan Santoso (2014) sebesar 1,45 .

\section{KESIMPULAN}

Penangkaran benih padi inbrida di Kecamatan Bumi Ratu Nuban Kabupaten Lampung Tengah cukup efisien dengan tingkat efisiensi sebesar 78,13 persen. Variabel penerimaan dan sumber modal berpengaruh positif, sedangkan variabel biaya dan status kepemilikan lahan berpengaruh negatif terhadap efisiensi teknis penangkaran benih padi inbrida. Kontribusi biaya variabel terhadap biaya total sebesar 68,76 persen lebih tinggi dibandingkan kontribusi biaya tetap terhadap biaya total sebesar 31,24 persen dan komponen struktur biaya terbesar yaitu biaya tenaga kerja sebesar 46,29 persen. Nilai penerimaan, produksi, dan harga lebih besar dari nilai BEP dan nilai $\mathrm{R} / \mathrm{C}$ atas biaya tunai dan total lebih besar dari 1 .

\section{DAFTAR PUSTAKA}

Ambarita, MM, Prasmatiwi FE, dan Nugraha A. 2014. Analisis efisiensi produksi frontier dan pendapatan usahatani kedelai Sekolah Lapangan Pengelolaan Tanaman Terpadu (SL-PTT) di Kecamatan Lampung Selatan. Jurnal Ilmu Ilmu Agribisnis, 2(4): 348-355. https://jurnal.fp.unila.ac.id/index.php/JIA/art icle/view/989. [4 April 2019].

BPSBTPH [Balai Pengawasan dan Sertifikasi Benih Tanaman Pangan dan Hortikultura] Provinsi Lampung. 2018. Permohonan Sertifikasi Benih Tanaman Pangan 2018. BPSBTPH Provinsi Lampung. Bandar Lampung.

Dinas Pertanian TPH [Tanaman Pangan dan Hortikultura] Provinsi Lampung. 2017. Kinerja Tanaman Pangan dan Hortikultura Provinsi Lampung Tahun 2013-2018. https://dinastph.lampungprov.go.id/. 
Direktorat Jenderal Tanaman Pangan. 2018. Rencana Kerja Kementerian/Lembaga Tahun 2019. Kementerian Pertanian. Jakarta. Fermadi O, Prasmatiwi FE, dan Kasymir E. 2015. Analisis efisiensi produksi dan keuntungan usahatani jagung di Kabupaten Ogan Komering Ulu Timur Sumatera Selatan. Jurnal Ilmu Ilmu Agribisnis, 3(1): 107-113. https://jurnal.fp.unila.ac.id/index.php/ JIA/article/view/1024. [4 April 2019].

Geasti, Haryono D, dan Affandi MI. 2019. Struktur biaya, titik impas, dan pendapatan usahatani padi di Kecamatan Seputih Raman Kabupaten Lampung Tengah. Jurnal Ilmu Ilmu Agribisnis, 7(3): 292-297. https://jurnal.fp.unila.ac.id/index.php/JIA/art icle/view/3765. [20 Maret 2020].

Handayani SA, Effendi I, dan Viantimala B. 2017. Produksi dan pendapatan usahatani padi di Desa Pujo Asri Kecamatan Trimurjo Kabupaten Lampung Tengah. Jurnal Ilmu Ilmu Agribisnis, 5(4): 422-429. https://jurnal.fp.unila.ac.id/index.php/JIA/art icle/view/1752. [24 Januari 2019].

Indah LSM, Zakaria WA, dan Prasmatiwi FE. 2015. Analisis efisiensi produksi dan pendapatan usahatani padi sawah pada lahan irigasi teknis dan lahan tadah hujan di Kabupaten Lampung Selatan. Jurnal Ilmu Ilmu Agribisnis, 3(3): 228-234. https://jurnal.fp.unila.ac.id/index.php/JIA/art icle/view/1046. [4 April 2019].

Misgiantoro R, Prasmatiwi FE, dan Nurmayasari I. 2017. Analisis efisiensi produksi dan pendapatan usahatani jahe di Kecamatan Penengahan Kabupaten Lampung Selatan. Jurnal Ilmu Ilmu Agribisnis, 5(1): 22-30. http://jurnal.fp.unila.ac.id/index.php/JIA/arti cle/view/2782. [4 April 2019].

Mita YT, Haryono D, dan Marlina L. 2018. Analisis pendapatan dan faktor-faktor yang mempengaruhi pengambilan keputusan usahatani penangkaran benih padi di Kabupaten Pesawaran. Jurnal Ilmu Ilmu Agribisnis, $\quad$ 6(2): $\quad$ 125-132. https://jurnal.fp.unila.ac.id/index.php/JIA/art icle/view/2777. [28 Januari 2019].

Noer SR, Zakaria WA, dan Murniati K. 2018. Analisis efisiensi produksi usahatani padi ladang di Kecamatan Sidomulyo Kabupaten Lampung Selatan. Jurnal Ilmu Ilmu Agribisnis, $\quad$ 6(1): $\quad$ 17-24.
http://jurnal.fp.unila.ac.id/index.php/JIA/arti cle/view/2492/0. [18 Juli 2019].

Rahim A dan Hastuti DRD. 2008. Ekonomika Pertanian. Penebar Swayada. Jakarta.

Saputra RD, Haryono D, dan Santoso H. 2014. Produksi dan pendapatan usahatani padi sawah hibrida dan inbrida di Kecamatan Gedong Tataan Kabupaten Pesawaran. Jurnal Ilmu Ilmu Agribisnis, 2(3): 196-205. https://jurnal.fp.unila.ac.id/index.php/ JIA /article/view/801. [24 Januari 2019].

Soekartawi. 1995. Analisis Usahatani. UI-Press. Jakarta.

Soekartawi. 2003. Teori Ekonomi Produksi dengan Pokok Bahasan Analisis Cobb-Douglas. PT Raja Grafindo Persada. Jakarta.

Sugiarto D, Sunaryanto S, dan Oetomo DS. 2003. Teknik Sampling. Gramedia Pustaka Utama. Jakarta.

Suratiyah K. 2015. Ilmu Usahatani. Penebar Swadaya. Jakarta.

Suripatty MP. 2011. Analisis struktur biaya produksi dan kontribusi pendapatan komoditi kakao (Theobroma cacao L.) di Desa Latu. Jurnal Agroforestri, 6(2): 135141. Error! Hyperlink reference not valid. https://jurnalee.files.wordpress.com/2012/12/ analisa-struktur-biaya-produksi-dankontribusi-pendapatan-komoditi-kakao.pdf. [12 April 2019].

Tristya H, Murniati K, dan Affandi MI. 2018. Efisiensi teknis usahatani bawang merah di Kecamatan Ketapang Kabupaten Lampung Selatan. Jurnal Ilmu Ilmu Agribisnis, 6(3): 222-228. https://jurnal.fp.unila.ac.id/index. php/JIA/article/view/3017. [20 Maret 2020].

Ulpah A, Tinaprilla N, dan Baga LM. 2018. Analisis efisiensi teknis usahatani penangkaran benih padi pola kemitraan di Kabupaten Subang: pendekatan Stochastic Frontier Analysis. Jurnal Pengkajian dan Pengembangan Teknologi Pertanian, 21(3): 259-275.

http://ejurnal.litbang.pertanian.go.id/index.p hp/jpengkajian/article/view/9342. [1 Juli 2019].

Usman M. 2011. Analisis Struktur Biaya dan Harga Pokok Produksi pada Usahatani Jagung di Kecamatan Lembah Seulawah Kabupaten Aceh Besar. Sains Riset, 1(2): 18. https://scholar.google.co.id/citations? user $=$ rRd1oWoAAAAJ\&hl=id. [4 Desember 2019]. 